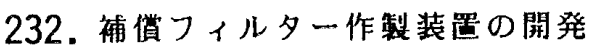

信州大学医学部附属病院
（その四）新ファンビームアルゴリズムとその補偵精度

放射線部门小口宏

放射線科潼沢 正臣

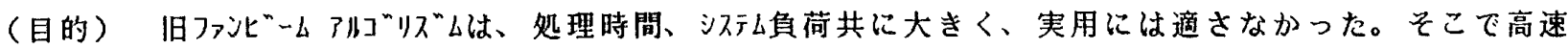

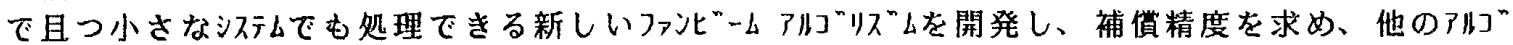
リズムとの違いを比較検討した。

（方法）不均晢を含む数種類のファントームよりそれぞれのア师゙リズしでフィ多ーを作製し、放射線治療計画装置 での線量分布、フィ㞦及び透過線麦実測による二次元線量分布を求めると共に、TLD線量計でフアンー 山内部の線量分布を测定し比校、検討した。

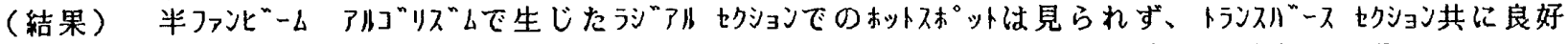
な補償効果が得られ、その補償精度は、士5\%以内であった。処理時間は最大 90 分である。

233. 写真フィルムによる高エネルギーX線の肺内線量分布䁚定法の再険討

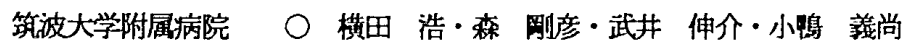

[目的及び方法] $6 \mathrm{MV} ・ 10 \mathrm{MVX}$ 線の肺内線量分布測定に写真フィルムを用いた埸合の精度訣価を J A R P 形線量計での実澌值と 比輍し、再険討を行う。検討した項目は１）フィルム面への平行ビームと垂直ビーム照射との比較、2）フィルム厚の補正

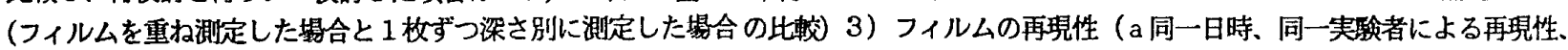

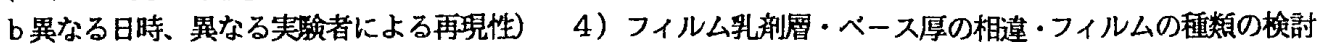

5) With packとWith out packの相違などについて再検討し J ARP形線量計で実測したPDDとの差及び、肺補正俰数の差を求め、 その精度部価を行った。［結果］ 1) 肺ファントム中のフィルム面への平行ビームと垂直ビーム照射によるPDDは一致しなかった。 2) 厚さ補正前でのフィルムのP D D J A R P 形線量計の値より小さくなったが、補正後では異なった。

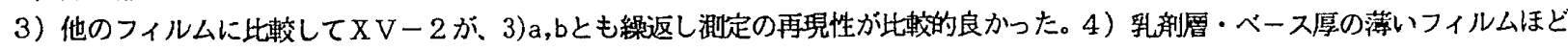
J A R P 形線量計の值に近かった。 5) With packとWith out packの相違による差は、それほどでなかった。

\title{
234．傍大動脈リンバ節領域の原体打抜き照射の検討
}

愛知県がんセンター放射線治療部 ○水谷武雄 木村千明 伊藤善之 内山幸男

（目的）子宮頚がんの放射線治療は、全骨盤腔及び傍大動脈りンバ節への照射がなされる。当施設では、傍大動脈 リンバ節領域への照射法は、脊跹線量を少なくするための考衤として、椎体弯曲㳊沿った打抜き吸収体を用いて原 体照射法を行っている。今回、治療計画がより简便となるよう過去の資料を整理し検討を行ったので報告する。

（方法）原体打抜き照射を行うために、椎体の弯曲に沿った打抜き吸収体を治療患者每に作成した 70 症例の望料

（側面のX線写真及ひ確認写真など）を基に以下の点について検討を行った。1）椎体弯曲度の测定。2）傍大動 脈りンバ節領域の照射野型の標準化及び打拔き吸収体の標準化。3）毎日の治療時における椎体位置の再現性につ いて調べた。

（結果） 椎体の弯曲度の測定を行い、体形化することにより傍大動脈りンバ節領域の照射野及び打抜き吸収体を三 次元的に標準化できた。適合精度も良く、治療計画においては简便化できた。

\section{5. 孚房保存放射敫治療技衔以関す当基磷的研究}

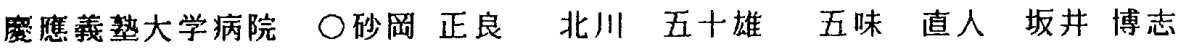

最近、我々の大学では乳ガンに対する治療に於て、畽瘍のみを摘出し放射線との併用によって乳 房保存治療が試みられている。そ己で、乳房保存治療に於けるフィールドの決め方や線量の分布 コントロールなどの技術に関する基礎的研究について報告する。フィールド決め方については患 例の内胸リンパ節を確実にそのフィールド内にいれることが重要であり線量の分布については単 に乳房の形のみで変化するものではなくフィールドの大きさや T a r g e t V o l u m e 内の 肺の占める割合などによっても変化することがわかった。 